\title{
Physiology and Pathophysiology of Proteinase-Activated Receptors (PARs): Role of Tryptase/PAR-2 in Vascular Endothelial Barrier Function
}

\author{
Yoshinori Itoh ${ }^{1, *}$, Toshiaki Sendo ${ }^{1}$, and Ryozo Oishi ${ }^{1}$ \\ ${ }^{1}$ Department of Pharmacy, Kyushu University Hospital, 3-1-1 Maidashi, Higashi-ku, Fukuoka 812-8582, Japan
}

Received October 12, 2004; Accepted November 9, 2004

\begin{abstract}
Proteinase-activated receptor-2 (PAR-2) plays important roles in a variety of pathophysiological functions, including inflammatory responses and nociception. In this minireview, we describe the role of PAR-2 in acute inflammatory responses in lungs associated with iodinated radiographic contrast medium (RCM). Intravenous injection of RCM to rats induces lung injury characterized by vascular hyperpermeability, edema, and respiratory depression. Nafamostat, which is found to be the most potent and specific tryptase inhibitor, prevents RCM-induced lung injury. In cultured endothelial cells of human pulmonary artery and bovine aorta, RCM, when applied in combination with mast cells, disrupts barrier function evaluated by the permeability of Evans blue through a monolayer of cultured cells, which is blocked by nafamostat and mimicked by tryptase and PAR-2-activating peptide. The tryptase-induced barrier dysfunction is blocked completely by a phospholipase $\mathrm{C}$ inhibitor and partially inhibited by a $\mathrm{IP}_{3}$ receptor blocker, protein kinase $\mathrm{C}$ inhibitor, or Rho kinase inhibitor. Morphological observations reveal the formation of actin stress fibers and disappearance of the intercellular meshwork structure of vascular endothelial-cadherin after application of RCM or PAR-2 ligands. Therefore, the release of mast cell tryptase and subsequent activation of endothelial PAR-2 are involved in acute lung injury induced by RCM.
\end{abstract}

Keywords: mast cell tryptase, nafamostat, radiographic contrast medium, vascular permeability, proteinase-activated receptor- 2

\section{Nafamostat is the most potent and specific tryptase inhibitor}

Tryptase is a serine protease that is included almost exclusively in mast cell granules (1). Mast cell tryptase is a potent modulator of microvascular leakage and inflammatory responses during episodes of allergic reactions (2). The concentration of tryptase is elevated in the plasma of asthmatic patients after allergen challenge $(3,4)$ and in the nasal lavage fluid of allergic patients $(5)$.

On the other hand, allergy-like adverse reactions including skin rush, blushing, and urticaria occur immediately after intravascular injection of radiographic contrast medium (RCM) (6). In severe cases, RCM causes bronchospasm, dyspnea, and pulmonary edema (7). The RCM-induced pulmonary edema is a noncardiogenic type and appears to be related to the increase

*Corresponding author. FAX: +81-92-642-5937

E-mail: yositou@st.hosp.kyushu-u.ac.jp in pulmonary vascular permeability due to the activation of the inflammatory cascade and the release of a variety of chemical mediators (8). It has been demonstrated that the plasma level of tryptase is elevated in patients who showed hypersensitivity reactions after intravascular injection of $\operatorname{RCM}(9,10)$. However, the role of mast cell tryptase in the pathogenesis of the anaphylactoid reactions to RCM remains to be clarified because of the lack of any available specific tryptase inhibitors.

Recently, Erba et al. (11) have reported that gabexate is a highly potent and specific inhibitor of human tryptase. This compound is a synthetic low molecularweight inhibitor of trypsin-like serine proteases (1214), but shows more than 100-fold higher affinity for human tryptase than for other proteases such as thrombin and trypsin. Gabexate is used clinically for the therapy of acute pancreatitis and disseminated intravascular coagulation in Japan.

We confirmed that gabexate inhibits the activity of 
human lung tryptase. More importantly, nafamostat, another structurally related serine protease inhibitor, was found to be far more potent than gabexate. In purified human tryptase, both gabexate and nafamostat inhibit tryptase activity in a concentration-dependent manner, in which $\mathrm{IC}_{50}$ values are $1.9 \times 10^{-7} \mathrm{M}$ for gabexate and $1.6 \times 10^{-11} \mathrm{M}$ for nafamostat (15). The mode of tryptase inhibition by these compounds is competitive (16). Moreover, the affinity of nafamostat for human tryptase is 157- and 8814-fold higher than those for trypsin and thrombin, respectively (16). Therefore, the compound appears to be useful for the research on the physiological roles of tryptase, although the biological half-life of this compound is short (23.1 $\mathrm{min})$ (17).

\section{Role of tryptase in RCM-induced acute lung injury in rats}

We have already found in rats that RCM causes extravasation of plasma proteins in lungs, pulmonary edema $(18,19)$, and respiratory dysfunction characterized by the decrease in arterial $\mathrm{PaO}_{2}$ and increase in $\mathrm{PaCO}_{2}(20,21)$ immediately (within $\left.10 \mathrm{~min}\right)$ after intravenous injection. These actions of RCM are partially blocked by histamine $\mathrm{H}_{1}$ - and $\mathrm{H}_{2}$-receptor antagonists, while markedly attenuated by cromoglycate, a mast cell stabilizer, and depletion of mast cells by repeated injection of compound 48/80 (22). Therefore, the RCM-induced acute lung injury may be mediated by mast cell ingredients. Indeed, RCM stimulates the release of pre-formed chemical mediators such as histamine $(23-26)$ and tryptase $(21,27,28)$ from mast cells without affecting the release of newly synthesized mediators such as leukotrienes $\mathrm{B}_{4}$ and $\mathrm{C}_{1}$, or prostaglandin $\mathrm{D}_{2}(29,30)$.

On the other hand, plasma extravasation in rat lungs induced by the intravenous injection of RCM is markedly reduced by nafamostat and slightly inhibited by gabexate (Fig. 1A). Nafamostat also prevents RCMinduced pulmonary edema (Fig. 1B) as well as the respiratory dysfunction (Fig. 1C). Therefore, it is suggested that mast cell tryptase contributes to the pathogenesis of acute lung injury induced by RCM.

\section{Regulation of barrier function by endothelial PAR-2}

Several lines of evidence have suggested that some of physiological actions of tryptase are mediated by the stimulation of proteinase-activated receptor (PAR)-2 $(31,32)$. PAR-2 is activated by its tethered ligand after cleavage of Arg-Ser bond near the N-terminal region by tryptase, trypsin, factor VIIa, and factor Xa $(33,34)$. The activation of PAR-2 results in the generation of nocicep- tive signals and pain (35), increase in airway resistance (36), and enhancement of vascular permeability $(37,38)$. Kawabata et al. (37) originally reported that PAR-2activating peptide (PAR-2AP) causes enhancement of vascular permeability and edema in rat hind paws. On the other hand, Steinhoff et al. (39) have shown that the vascular action of PAR-2AP in rat hind paws is due to the release of sensory peptides such as calcitonin generelated peptide and substance $P$ from sensory nerve endings. Indeed, PAR-2 is expressed in sensory nerves, and activation of this receptor stimulates the release of sensory peptides (39). Although both PAR-2 mRNA and its protein are highly expressed in vascular endothelial cells $(40,41)$, it is still uncertain whether endothelial PAR-2 directly regulates the barrier function.

In cultured monolayer of bovine aortic endothelial cells (BAEC) (15) or human pulmonary arterial endothelial cells (HPAEC) (21), RCM causes a marked and concentration-dependent increase in the permeability of proteins, when it is applied in combination with mast cells. The RCM-induced increase in endothelial permeability is suppressed by cromoglycate and nafamostat (15), thereby suggesting that the barrier dysfunction is mediated predominantly by mast cell tryptase. Indeed, tryptase causes a marked and concentration-dependent increase in endothelial permeability in BAEC (Fig. 2A), and this action is inhibited by nafamostat and gabexate in a concentration-dependent manner (Fig. 2B). In addition, the endothelial permeability is enhanced by PAR-2AP such as SLIGKV-NH 2 but not its reverse peptide LSIGKV-NH (Fig. 2A). Taken together, it is highly probable that RCM-induced barrier dysfunction is due to the activation of endothelial PAR-2.

In contrast to our data, it has been reported that PAR-2 stimulation does not affect barrier function in cultured human umbilical vein endothelial cells $(42,43)$. Although the reason for such a discrepancy is not known, differences in blood vessels (aorta and vein) or species may cause such a different role of PAR-2 in endothelial barrier function.

\section{Intracellular signaling involving PAR-2-mediated increase in permeability through monolayer of cul- tured endothelial cells}

It has been demonstrated that activation of PAR-2 stimulates phosphatidylinositol hydrolysis and results in the elevation of $\left[\mathrm{Ca}^{2+}\right]_{i}$ in numerous types of cells (33, 44) including endothelial cells (45), in which PAR-2 is coupled with $G$ proteins $\mathrm{G}_{\mathrm{q}} / \mathrm{G}_{11}$ (33). In BAEC, tryptase or PAR-2AP causes a marked elevation of $\left[\mathrm{Ca}^{2+}\right]_{i}$ and desensitization occurs after repeated stimulation (15). The PAR-2-mediated increase in endo- 
A)

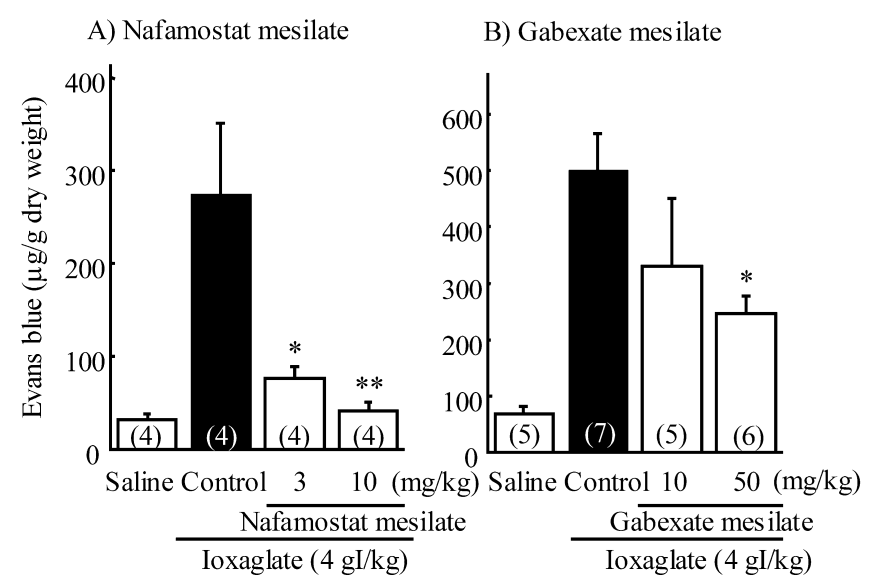

B)

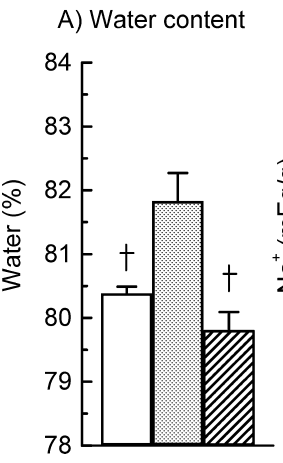

C)
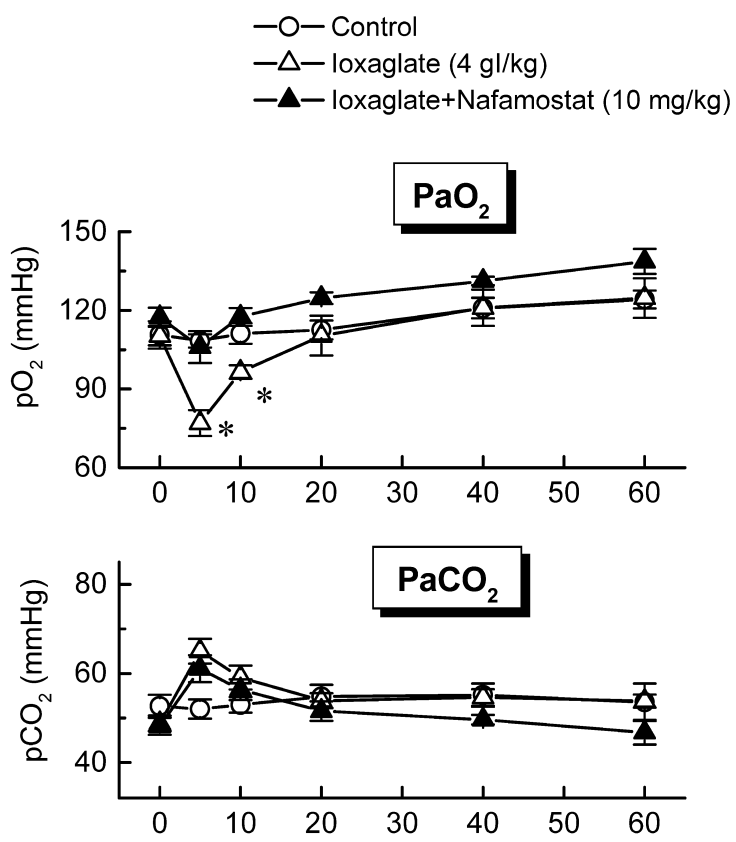

pH

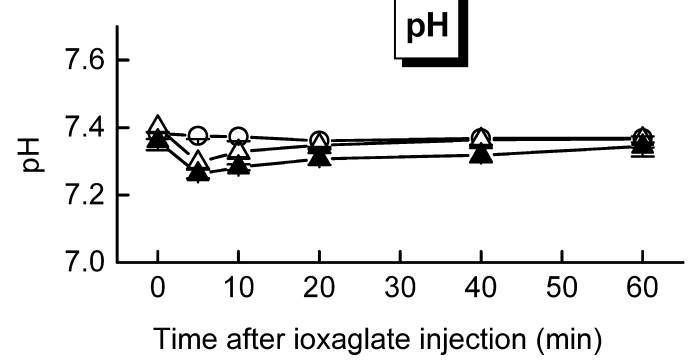

Fig. 1. Inhibition by nafamostat and gabexate of the vascular hyperpermeability in lungs (A), pulmonary edema (B), and respiratory dysfunction $(C)$ induced by the intravenous injection of RCM in rats. Respiratory dysfunction is assessed by monitoring arterial gasses. ${ }^{*} P<0.05,{ }^{*} P<0.01 v s$ control; ${ }^{\dagger} P<0.05 v s$ ioxaglate alone. Data from Sendo et al. (Ref. 21)

thelial permeability is reversed almost completely by the phospholipase C (PLC) inhibitor U73122 and partially inhibited by the protein kinase C (PKC) inhibitor calphostin $\mathrm{C}$, the 1,4,5-trisphosphate $\left(\mathrm{IP}_{3}\right)$-receptor antagonist xestospongin $\mathrm{C}$, or the Rho kinase inhibitor Y27632 (15). Therefore, activation of PKC and Rho kinase and elevation of $\left[\mathrm{Ca}^{2+}\right]_{\mathrm{i}}$ may contribute to PAR-2mediated endothelial barrier dysfunction.

Formation of actin stress fibers and disappearance of VE-cadherin structure after PAR-2 activation in cultured endothelial cells

The endothelial barrier function is regulated by the intercellular tight junctional organization. Vascular endothelial (VE)-cadherin is the major constituent of cell-to-cell contact and interacts with actin filaments via associated proteins such as $\alpha$ - and $\beta$-catenins (46). The VE-cadherin-catenin complex is flexible and disappears from the extracellular surface in response to various stimuli such as thrombin that disrupt endothelial barrier function (47). The gap formation due to the formation of actin stress fibers and its interaction with myosin is also involved in endothelial barrier dysfunction (48). Stimulation of BAEC with tryptase or PAR2AP causes disappearance of immunoreactive VEcadherin with a marked development of actin stress fiber $(15,21)$. RCM, when applied in combination with mast cells, also results in similar change in VE-cadherin immunoreactivity and actin stress fiber formation (15, 21). It has been reported that stimulation of PAR-2 results in the rapid activation of RhoA and subsequent formation of actin stress fibers in prostate cancer cell line LNCaP cells (49) as well as in endothelial cells (50). 


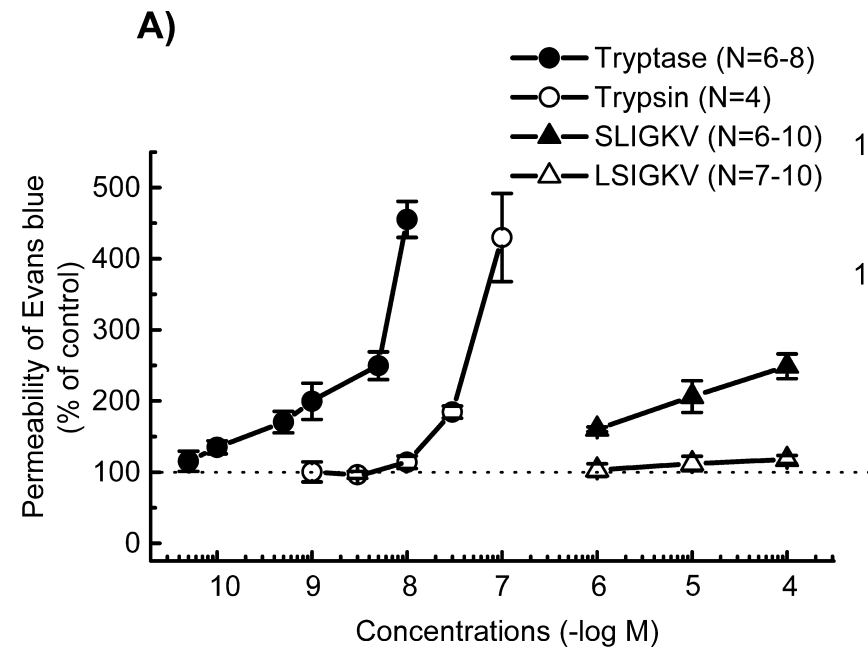

B)

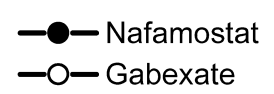

Fig. 2. Enhancement of permeability of BAEC by tryptase, trypsin, and a synthetic PAR-2-activating peptide SLIGKV-NH but not its reverse peptide LSIGKV-NH $\mathrm{N}_{2}(\mathrm{~A})$ and reversal by nafamostat and gabexate of tryptase-induced increase in endothelial permeability (B). Data from Sendo et al. (Ref. 15)

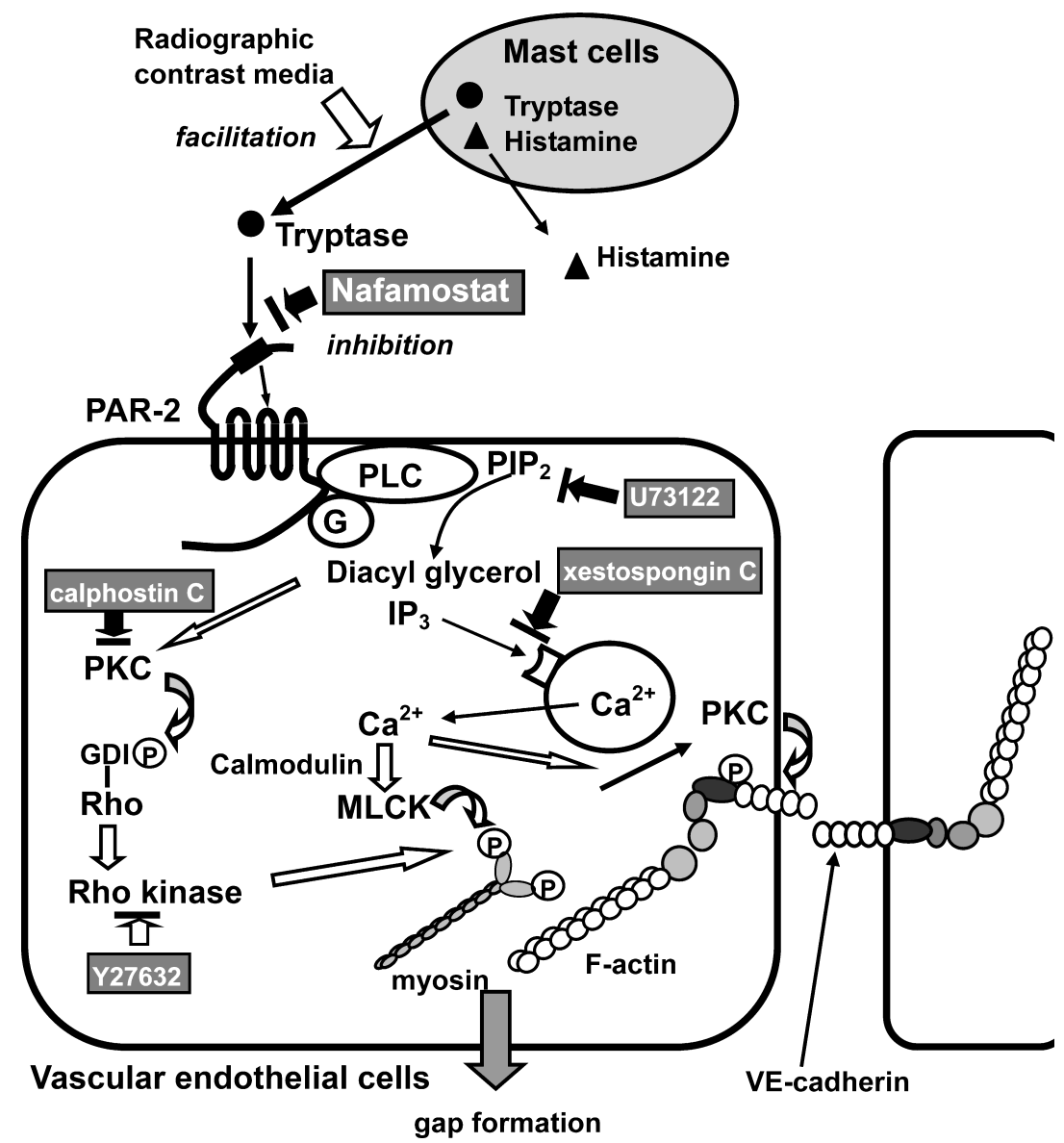

Fig. 3. Schematic drawing for possible cellular mechanisms underlying endothelial barrier dysfunction induced by radiographic contrast medium (RCM). RCM causes degranulation of mast cells and stimulates the release of tryptase, which in turn, activates endothelial PAR-2. The elevation of intracellular $\mathrm{Ca}^{2+}$ and activation of PKC after PAR-2 stimulation may trigger the formation of actin stress fibers and disappearance of tight junctional proteins such as VE-cadherin, which leads to barrier dysfunction. GDI: guanine nucleotide dissociation inhibitor, MLCK: myosin light chain kinase. 
Since PAR-2-mediated increase in permeability through a monolayer of BAEC is attenuated by Y27632, the activation of RhoA/Rho kinase may play a role in PAR-2-mediated gap formation.

\section{Conclusion}

We demonstrated for the first time that the release of mast cell tryptase and subsequent activation of PAR-2 are implicated in the pathogenesis of acute lung injury induced by RCM. Moreover, the endothelial PAR-2 regulates directly the barrier function in some arteries. The cellular mechanisms underlying RCM-induced endothelial barrier dysfunction is summarized in Fig. 3. RCM is a potent secretagogue of mast cell substances such as histamine and tryptase. The released tryptase activates endothelial PAR-2 and results in the formation of $\mathrm{IP}_{3}$ and diacylglycerol via activation of PLC. Both PKC stimulated by diacylglycerol and elevation of $\left[\mathrm{Ca}^{2+}\right]_{\mathrm{i}}$ via stimulation of $\mathrm{IP}_{3}$ receptor are involved in endothelial barrier dysfunction, in which Rho kinasedependent gap formation and disappearance of VEcadherin structure are involved.

In this respect, the potent and selective tryptase inhibitor nafamostat may be potentially useful for prophylaxis of severe pulmonary injury associated with radiographic examination in high-risk patients.

\section{References}

1 Schwartz LB. Tryptase, a mediator of human mast cells. J Allergy Clin Immunol. 1990;86:594-598.

2 He S, Walls AF. Human mast cell tryptase: a stimulus of microvascular leakage and mast cell activation. Eur J Pharmacol. 1997;328:89-97.

3 Wenzel SE, Fowler AA, Schwartz LB. Activation of pulmonary mast cells by bronchoalveolar allergen challenge. In vivo release of histamine and tryptase in atopic subjects with or without asthma. Am Rev Respir Dis. 1988;137:1002-1008.

4 Swystun VA, Gordon JR, Davis EB, Zhang X, Cockcroft DW. Mast cell tryptase release and asthmatic responses to allergen increase with regular use of salbutamol. J Allergy Clin Immunol. 2000;106:57-64.

5 Jacobi HH, Skov PS, Kampen GT, Poulsen LK, Reimert CM, Bindslev-Jensen $\mathrm{C}$, et al. Histamine and tryptase in nasal lavage fluid following challenge with methacholine and allergen. Clin Exp Allergy. 1998;28:83-91.

6 Katayama H, Yamaguchi K, Kozuka T, Takashima T, Seez P, Matsuura K. Adverse reactions to ionic and nonionic contrast media. A report from the Japanese Committee on the Safety of Contrast Media. Radiology. 1990;175:621-628.

7 Madowitz JS, Schweiger MJ. Severe anaphylactoid reaction to radiographic contrast media. Recurrences despites premedication with diphenhydramine and prednisone. JAMA. 1979;241: 2813-2815.

8 Bouachour G, Varache N, Szapiro N, L'Hoste P, Harry P,
Alquier P. Noncardiogenic pulmonary edema resulting from intravascular administration of contrast material. Am J Roentgenol. 1991;157:255-256.

9 Mita H, Tadakoro K, Akiyama K. Detection of IgE antibody to a radiocontrast medium. Allergy. 1998;53:1133-1140.

10 Laroche D, Aimone-Gastin I, Dubois F, Huet H, Gerard P, Vergnaud MC, et al. Mechanisms of severe, immediate reactions to iodinated contrast material. Radiology. 1998;209:183-190.

11 Erba F, Fiorucci L, Pascarella S, Menegatti E, Ascenzi P, Ascoli F. Selective inhibition of human mast cell tryptase by gabexate mesilate, an antiproteinase drug. Biochem Pharmacol. 2001; 61:271-276.

12 Menegatti E, Bolognesi M, Scalia S, Bortolotti F, Guarneri M, Ascenzi P. Gabexate mesylate inhibition of serine proteases: thermodynamic and computer-graphics analysis. J Pharm Sci. 1986;75:1171-1174.

13 Aramoto H, Saito H, Shigematsu H, Muto T. Synthetic protease inhibitors in the treatment of disseminated intravascular coagulation. Nippon Rinsho. 1993;51:93-98. (text in Japanese with English abstract)

14 Ramjee MK, Henderson IM, McLoughlin SB, Padova A. The kinetic and structural characterization of the reaction of nafamostat with bovine pancreatic trypsin. Thromb Res. 2000; 98:559-569.

15 Sendo T, Sumimura T, Itoh Y, Goromaru T, Aki K, Yano T, et al. Involvement of proteinase-activated receptor-2 in mast cell tryptase-induced barrier dysfunction in bovine aortic endothelial cells. Cell Signal. 2003;15:773-781.

16 Mori S, Itoh Y, Shinohata R, Sendo T, Oishi R, Nishibori M. Nafamostat mesilate is an extremely potent inhibitor of human tryptase. J Pharmacol Sci. 2003;92:420-423.

17 Tsukagoshi S. Pharmacokinetics studies of nafamostat mesilate (FUT), a synthetic protease inhibitor, which has been used for the treatments of DIC and acute pancreatitis, and as an anticoagulant in extracorporeal circulation. Gan To Kagaku Ryoho. 2000;27:767-774. (text in Japanese with English abstract)

18 SendoT, Hirakawa M, Fujie K, Kataoka Y, Oishi R. Contrast medium-induced pulmonary edema is aggravated by silicone contamination in rats. Radiology. 1999;212:97-102.

19 Sendo T, Kataoka Y, Takeda Y, Furuta W, Oishi R. Nitric oxide protects against contrast media-increased pulmonary vascular permeability in rats. Invest Radiol. 2000;35:472-478.

20 Sendo T, Goromaru T, Aki K, Sakai N, Itoh Y, Oishi R. Carbazochrome attenuates pulmonary dysfunction induced by a radiographic contrast medium in rats. Eur J Pharmacol. 2002; 450:203-208.

21 Sendo T, Itoh Y, Goromaru T, Sumimura T, Aki K, Yano T, et al. A potent tryptase inhibitor nafamostat mesilate dramatically suppressed pulmonary dysfunction induced by a radiographic contrast medium. Br J Pharmacol. 2003;138:959-967.

22 Goromaru T, Sendo T, Itoh Y, Sakai N, Teshima D, Oishi R. Evidence for an involvement of mast cell degranulation and subsequent stimulation of histamine $\mathrm{H}_{1}$ and $\mathrm{H}_{2}$ receptors in radiographic contrast media-increased vascular permeability in rats. Naunyn Schmiedebergs Arch Pharmacol. 2002;366:605612.

23 Ennis M, Lorenz W, Nehring E, Schneider C. In vitro and in vivo studies of radiographic contrast media-induced histamine release in pigs. Agents Actions. 1991;33:26-29.

24 Peachell PT, Morcos SK. Effect of radiographic contrast media 
on histamine release from human mast cells and basophils. Br J Radiol. 1998;71:24-30.

25 Saito M, Itoh Y, Sendo T, Yano T, Goromaru T, Sakai N, et al. Roles of intracellular $\mathrm{Ca}^{2+}$ and cyclic AMP in mast cell histamine release induced by radiographic contrast media. Naunyn Schmiedebergs Arch Pharmacol. 2003;367:364-371.

26 Itoh Y, Sendo T, Saito M, Yano T, Goromaru T, Kubota T. Comparison of cellular mechanisms underlying histamine release from rat mast cells induced by ionic and non-ionic radiographic contrast media. Invest Radiol. 2004;39:455-461.

27 Stellato C, de Crescenzo G, Patella V, Mastronardi P, Mazzarella B, Marone G. Human basophil/mast cell releasability. XI. Heterogeneity of the effects of contrast media on mediator release. J Allergy Clin Immunol. 1996;97:838-850.

28 Rodriguez RM, Gueant JL, Gastin IA, Angioi M, Abdelmoutaleb I, Saint-Laudy J, et al. Comparison of effects of ioxaglate versus iomeprol on histamine and tryptase release in patients with ischemic cardiomyopathy. Am J Cardiol. 2001; $88: 185-188$

29 Romano M, Di Bello M, Salmona M, Piovani B, Rosati G. Effect of iodinated contrast media on the synthesis and metabolism of leukotriene B4. Invest Radiol. 1991;26:348-352.

30 Genovese A, Stellato C, Patella V, Lamparter-Schummert B, de Crescenzo G, Adt M, et al. Contrast media are incomplete secretagogues acting on human basophils and mast cells isolated from heart and lung, but not skin tissue. Int J Clin Lab Res. 1996;26:192-198.

31 Nystedt S, Emilsson K, Wahlestedt C, Sundelin J. Molecular cloning of a potential proteinase activated receptor. Proc Natl Acad Sci USA. 1994;91:9208-9212.

32 Böhm SK, Kong W, Bromme D, Smeekens SP, Anderson DC, Connolly A, et al. Molecular cloning, expression and potential functions of the human proteinase-activated receptor-2. Biochem J. 1996;314:1009-1016.

33 Corvera CU, Dery O, McConalogue K, Bohm SK, Khitin LM, Caughey $\mathrm{GH}$, et al. Mast cell tryptase regulates colonic myocytes through proteinase-activated receptor-2. J Clin Invest. 1997;100:1383-1393.

34 Molino M, Barnathan ES, Numerof R, Clark J, Dreyer M, Cumashi A, et al. Interaction of mast cell tryptase with thrombin receptors and PAR-2. J Biol Chem. 1997;272:4043-4049.

35 Hoogerwerf WA, Zou L, Shenoy M, Sun D, Micci MA, LeeHellmich $\mathrm{H}$, et al. The proteinase-activated receptor 2 is involved in nociception. J Neurosci. 2001;21:9036-9042.

36 Ricciardolo FL, Steinhoff M, Amadesi S, Guerrini R, Tognetto $\mathrm{M}$, Trevisani M, et al. Presence and bronchomotor activity of protease-activated receptor-2 in guinea pig airways. Am J Resp Crit Care Med. 2000;161:1672-1680.

37 Kawabata A, Kuroda R, Minami T, Kataoka K, Taneda M. Increased vascular permeability by a specific agonist of protease-activated receptor- 2 in rat hind paw. $\mathrm{Br} \mathrm{J}$ Pharmacol.
1998;125:419-422.

38 Vergnolle N, Wallace JL, Bunnett NW, Hollenberg MD. Characterization of the inflammatory response to proteinaseactivated receptor-2 (PAR-2)-activating peptides in the rat paw. Trends Pharmacol Sci. 2001;22:146-152.

39 Steinhoff M, Vergnolle N, Young SH, Tognetto M, Amadesi S, Ennes HS, et al. Agonists of proteinase-activated receptor 2 induce inflammation by a neurogenic mechanism. Nat Med. 2000;6:151-158.

40 Nystedt S, Ramakrishnan V, Sundelin J. The proteinase-activated receptor 2 is induced by inflammatory mediators in human endothelial cells. Comparison with the thrombin receptor. J Biol Chem. 1996;271:14910-14915.

41 Molino M, Raghunath PN, Kuo A, Ahuja M, Hoxie JA, Brass LF, et al. Differential expression of functional protease-activated receptor-2 (PAR-2) in human vascular smooth muscle cells. Arterioscler Thromb Vasc Biol. 1998;18:825-832.

42 Compton SJ, Cairns JA, Holgate ST, Walls AF. Human mast cell tryptase stimulates the release of an IL-8-dependent neutrophil chemotactic activity from human umbilical vein endothelial cells (HUVEC). Clin Exp Immunol. 2000;121:31-36.

43 Klarenbach SW, Chipiuk A, Nelson RC, Hollenberg MD, Murray AG. Differential actions of PAR2 and PAR1 in stimulating human endothelial cell exocytosis and permeability: the role of Rho-GTPases. Circ Res. 2003;92:272-278.

44 Berger P, Tunon-De-Lara JM, Savineau JP, Marthan R. Selected contribution: tryptase-induced PAR-2-mediated $\mathrm{Ca}^{2+}$ signaling in human airway smooth muscle cells. J Appl Physiol. 2001; 91:995-1003.

45 Mirza H, Yatsula V, Bahou WF. The proteinase activated receptor-2 (PAR-2) mediates mitogenic responses in human vascular endothelial cells. J Clin Invest. 1996;97:1705-1714.

46 Lampugnani MG, Corada M, Caveda L, Breviario F, Ayalon O, Geiger B, et al. The molecular organization of endothelial cell to cell junctions: differential association of plakoglobin, $\beta$ catenin, and $\alpha$-catenin with vascular endothelial cadherin (VE-cadherin). J Cell Biol. 1995;129:203-217.

47 Rabiet MJ, Plantier JL, Rival Y, Genoux Y, Lampugnani MG, Dejana E. Thrombin-induced increase in endothelial permeability is associated with changes in cell-to-cell junction organization. Arterioscler Thromb Vasc Biol. 1996;16:488-496.

48 Garcia JG, Schaphorst KL. Regulation of endothelial cell gap formation and paracellular permeability. J Investig Med. 1995; 43:117-126.

49 Vouret-Craviari V, Grall D, Van Obberghen-Schilling E. Modulation of Rho GTPase activity in endothelial cells by selective proteinase-activated receptor (PAR) agonists. J Thromb Haemost. 2003;1:1103-1111.

50 Greenberg DL, Mize GJ, Takayama TK. Protease-activated receptor mediated RhoA signaling and cytoskeletal reorganization in LNCaP cells. Biochemistry. 2003;42:702-709. 